\title{
An Interactive Teaching - Learning Tool for Underprivileged Children in Rural Schools
}

\author{
H. Vignesh Ramamoorthy \\ Assistant Professor, Department of Computer Science, \\ Sree Saraswathi Thyagaraja College, Pollachi-642107, Coimbatore District, India \\ Email: hvigneshram@gmail.com \\ P.J.Balaku maran \\ Research Scholar, Research Department of Computer Applications, \\ Sree Saraswathi Thyagaraja College, Pollachi-642107, Coimbatore District, India \\ Email:blkumarn@gmail.com \\ H.Karthikeyani \\ PG Scholar, Department of Mathematics, \\ Nallamuthu Gounder Mahalingam College, Pollachi-642001, Coimbatore District, TN, India \\ Email: hkarthikeyani@gmail.com
}

\begin{abstract}
In a country like India, there are children who starve for food, water and cannot spend time for studying and they have to work hard, to get one meal a day. The dropouts in schools are high because of various reasons. Education is not at affordable cost, government must bring some schemes. $80 \%$ schools suffer from shortage of teachers, infrastructural gaps and several habitations. There are also frequent allegations of government schools being riddled with absenteeism and mis management and appointments are based on political convenience. Despite the allure of free lunch-food in the government schools, many parents send their children to private schools. As a result, proponents of low cost private schools, critiqued government schools as being poor value for money. Furthermore, many international schools with most modern Information Communication Technology (ICT) tools are mushrooming even in remote villages because the rural elites who are able to afford school fees in a country where large number of families live in absolute poverty. The major objective of this paper is to develop an interactive teaching-learning tool with multimedia applications for underprivileged children in rural schools. This tool will help the rural school children to have quality education at an affordable cost.
\end{abstract}

Index Terms - Education, Information, Commun ication, Technology and Multimedia.

\section{INTRODUCTION}

The term Education [1] is the act or process of imparting or acquiring general knowledge. The "history of education in the Indian subcontinent [2] began with teaching of traditional elements such as Indian religions, Indian mathematics, Indian logic at early Hindu and Buddhist centers of learning such as Taxila (in modernday Pakistan) and Nalanda (in India) before the common era. The right to education (RTE) [3] is a universal entitlement to education, a right that is recognized as a human right. According to the International Covenant on Economic, Social and Cultural Rights the right to education includes the right to free, compulsory primary education for all an obligation to develop secondary education accessible to all, in particular by the progressive introduction of free secondary education. The right to education is enshrined in Article 26 of the Universal Declaration of Human Rights and Articles 13 and 14 of the International Covenant on Economic, Social and Cultural Rights [3]. The right to education has been reaffirmed in the 1960 UNESCO Convention against Discrimination in Education and the 1981 Convention on the Elimination of All Forms of Discrimination against Women. Education depends on the country's economic status, tradition, people etc. The right to education is universally recognized, the way it is interpreted at the national level differs substantially. This means that although every human being holds the same right regardless of any national law, the ways of securing this right vary greatly from location to location. For example, in some countries the right to education may be legally enforceable through national legislation, while in others it will be important to look to international law and standards [3].

The term education [1] refers to the act or process of imparting or acquiring general knowledge, developing the powers of reasoning and judgment, and generally of preparing oneself or others intellectually for mature life; a degree, level, or kind of schooling: a university education; the result produced by instruction, training, or study: to show one's education; the science or art of teaching; pedagogic [1]. School education is the basement for any child. There are some global issues in the child education. Around the world many children are facing the problems like poverty, sexual harassment, child labor etc. This is all because the education system is not affordable and the governments do not have 
proper schemes to provide basic education to their country children. Rural schools have children from Indigenous groups, minorities and Below Poverty Line families. This is the main reason behind choosing the rural villages in Tamil Nadu as the target area for intensive intervention. This paper proposes to develop an interactive teaching-learning tool with multimedia applications for underprivileged children in rural schools. This tool will help the rural school children to have quality education at affordable cost. This paper discusses the existing situation of Educational Systems in Tamil Nadu (a state of Southern India), the problems in education, the objectives and the proposed system.

This paper proposes an Interactive Teaching Learning Tool for Underprivileged Children in Rural Schools. Section II describes briefly about the institutional education in India, Section III illustrates on the existing situation of educational systems in India. Significance of the problem is discussed in Section IV, the current situation in Tamil Nadu is described in Section V. The proposed system is given in Section VI. Finally this paper is concluded in Section VII.

\section{INSTITUTIONAL EDUCATION IN INDIA}

A plethora of govern ment in itiatives to provide access to primary education may be underway, but issues of equity, quality and access remain areas of concern particularly in rural schools [5]. Children in rural areas continue to be deprived of quality education owing to factors like lack of competent and committed teachers, lack of textbooks or teaching-learning materials, and so on. Under the Constitution of India, education is a concurrent subject, with a sharing of responsibilities (including legislation) between the Centre (Ministry of Human Resource Development) and States (Departments of Education). Management of schooling has been traditionally controlled by the mainstream state and district administrations. The last two decades have seen the emergence of a number of education-specific support institutions, such as the District Primary Education Programme (DPEP) and Sarva Shiksha Abhiyan (SSA) [6] State Implementation Societies, State Councils of Educational Research and Training (SCERT), State Institutes of Educational Management and Training (SIEMAT), District Institutes of Education and Training (DIET), Block Resource Centres (BRC), Cluster Resource Centres (CRC), and, in rural areas, Village Education Committees (VEC), as well as an increased involvement of NGOs, that have acted as a counterweight to what is often an overly bureaucratic and hierarchical ad ministration.

The last decade or so has also seen the establishment of the Panchayati Raj, or village council, and this body is playing an increasingly important role in education in rural areas across the country [5]. There are broadly four stages of school education in India: namely, primary, upper primary, secondary education (SE), and higher secondary education (HSE). The combination of primary and upper primary schooling is termed elementary education [8]. It is important to note that there is also a programme of pre-school education (for three to six year olds), early childhood care and education (ECCE), mostly provided through the Department of Women and Child Development (DWCD), GOI through Anganwadi Centre infrastructure.

There are also a few other government and private providers of pre-school and nursery education in rural areas. At the other end of the system, there is technical and vocational education as well as training and higher education involving universities and undergraduate and postgraduate institutions. The structure of education has four basic types of school:

1. Government schools, including those run by local bodies;

2. Private schools, aided by the government;

3. Private unaided schools; and

4. Unrecognized private schools (the first three being recognized by the government).

Eighty-seven per cent of the schools in India are in the country's villages.

\section{EXISTING SITUATION OF EDUCATIONAL SYSTEMS IN INDIA}

The education infrastructure holds the Ward which finds that through the Serva Shiksha Abhiyan (SSA) $[4,6]$ there has been remarkable progress in increasing access to pre-school and elementary education in rural areas, particularly over the past ten years or so. The rural road connectivity has lowered the teacher's absenteeism in village schools. Of course, several problems such as irregular attendance of children and teachers, low levels of time on task and gaps in provision still persist and the issue of how to ensure a quality education for all remains. But these challenges are being addressed and there are positive signs that the emphasis on major government programmes such as SSA is shifting from universal enrolment to universal retention and quality. In tandem with this, increasing attention is being given to the governance of schools [5] with the formation and functioning of VECs and more transparent processes for managing school resources.

The next challenge is to increase access in rural areas to secondary education, particularly for girls, SC, ST and minorities, and technical and vocational education and skills. Private sector service provisioning is emerging in a big way. But in both elementary and secondary education, better services will only come about with greater expansion of infrastructure, both within and around schools. This will require, in part, larger allocations to education. It will require the continuation of strong central support for policy, strategy, technical assistance and monitoring, and evaluation combined with increased decentralization within govern ment; stronger public-private partnerships; and improved accountability relationships between the service providers, policy makers, and consumers. The states in India have some policies in school education. The family is the main source of education for the child. 
Parents are entitled to provide education outside the school system if they wish. The state may not force parents to send their children to any school or any particular kind of school. Parents may decide the school to which they wish to send their children but there is no constitutional obligation on a particular school to accept individual children [5]. The state may require that the children receive a certain minimum education. This certain minimum has not yet been defined in legislation or in official policy. Many of the court cases have been about the precise meaning of that phrase. The state is obliged to provide for free primary education. It is not obliged to provide that education directly. In practice, there are some state schools but the majority of primary schools are privately owned and largely state funded. The state is not obliged to directly provide schools but it is not prevented from doing so either $[4,6]$.

\section{SIGNIFICANCE OF THE PROBLEM}

In a country like India where there are children who starve for food, water and cannot spend time for studying and they work for getting one time meal a day.

The dropouts in schools are high because of various reasons. These problems are because of two main reasons.

1. Education is not at affordable cost, government must bring some schemes

2. Lack of interest, the teaching and learning strategy should be changed

The quality of education provided by the government system remains in question. While it remains the largest provider of elementary education in the country forming $80 \%$ of all recognized schools, it suffers from shortages of teachers, infrastructural gaps and several habitations continue to lack schools altogether $[7,8]$. There are also frequent allegations of government schools being riddled with absenteeism and mis management and appointments are based on political convenience. Despite the allure of free lunch-food in the government schools, many parents send their children to private schools. Average school teacher salaries in private rural schools in some States (about Rs. 4,000 per month) are considerably lower than that in government schools. As a result, proponents of low cost private schools, critiqued government schools as being poor value for money. Children attending the private schools are seen to be at an advantage, thus discriminating against the weakest sections are forced to go to government schools [9,10]. Furthermore, many international schools with most modern Information Communication Technology (ICT) tools are mushrooming even in remote villages because the rural elites who are able to afford school fees in a country where large number of families live in absolute poverty.

\section{SITUATION IN TAMIL NADU}

In Tamil Nadu there are many rural areas where the above problems are more in rate. A survey was conducted in the city of Coimbatore. Lack of interest and proper parental guidance, domestic work and economic difficulties that pushed children into child labor, were the major reasons for students dropping out of schools, revealed a survey by Sarva Shiksha Abhiyan (SSA) $[4,6]$ conducted at the end of the academic year 2011-12. Out of the 6, 78, 255 children in the age group of 5-14 in Coimbatore education district, 4, 76, 803 attended school. While 1,040 students dropped out because of lack of interest in studies, around 560 students could not attend school because of domestic labor, Migration was the reason for 330 students dropping out of schools. According to the survey, 330 students dropped out because of economic difficulties while 385 students were additional earning members of their family. The survey also revealed that out of the 38,232 out of school children who dropped out, never enrolled in schools. Around 50 children in the age group of 6-14 had never enrolled in schools [8]. The survey also identified children of migrant labors from Andhra Pradesh, Kerala, Orissa, West Bengal, Bihar, Uttar Pradesh and Rajasthan, who were out of school. Children of inter-state and inter-state migrants also contributed to the increase in number of out of school children in the district [10]. These children were identified near construction sites in places including Perur, S.S.Kulam, Papanacieknplayam, Thondamuthur, Pollachi and Tirupur. Our study is going to be conducted by Sree Saraswathi Thyagaraja College in Pollachi in Coimbatore District, Tamil Nadu. Pollachi is a very small town located in the district of Coimbatore. There are many villages in and around Pollachi. These rural areas contain many school dropouts. Lack of infrastructural facilities, inadequate teaching-learning materials, absence of ICT tools, lack of extracurricular activities and less number of resources are the major drawbacks facing by the schools in Tamil Nadu rural villages [5, 8]. In general, school teachers:

- identify children's individual and collective learning needs

- plan and deliver instruction based on student learning needs

- $\quad$ provide a stimulating learning environment in which each child can experience growth and develop to potential

- help students learn appropriate knowledge, skills and attitudes

- facilitate positive social relationships between students

- use various assessment tools to evaluate and communicate student progress

- $\quad$ serve as role models for students.

Classes vary in size and include students who represent a broad range of abilities, interests and needs. A variety of instructional and assessment strategies are required to maintain student interest and maximize individual learn ing.

In addition, teachers:

- meet with parents 
- meet with other professionals to discuss individual student needs and progress

- organize and direct the work of teacher assistants and parent volunteers

- $\quad$ supervise extra-curricular and after school activities

- attend meetings, seminars and professional development sessions

- deal with children's crises such as forgotten lunches, minor scrapes, family emergencies or not being picked up as scheduled.

Most teachers are responsible for a homeroom class of 40 to 50 children and teach most subjects. Some teachers teach music, second languages or physical education at different grade levels. Teachers programs focus on the development of positive self-concepts in young children and include planning, organizing and providing a wide variety of developmentally appropriate experiences that foster understanding and use of language through:

- hands on activities, stories, discussions, songs, art, games and other exploratory learning activities

- $\quad$ listening experiences

- individual and group activities and projects.

These are happening only in costly private schools and very few government schools in India. The above said activities should be incorporated in all the government schools of India.

\section{THE PROPOSED SYSTEM}

This paper after development will cater to the needs of children of rural poor through a well-equipped ICT based education tool to capacitate teachers to adapt with technological innovations and its implementation in teaching process. This will facilitate the students to understand subjects through multi-dimensional perspective with the help of ICT. Fig. 1 and Fig. 2 depict the interactive teaching-learning tool with multimedia applications. The major objective of this paper is to develop an interactive teaching-learning tool with multimedia applications for underprivileged children in rural schools.

- $\quad$ Evolve an ICT tool for teaching-learning

- Developing internal mechanism to run the tool

- Facilitate the schools to receive and operate the tool

- Capacitate teachers and students to utilize the tool

This paper focuses on three major innovative models:

1. Evolving a teaching-learning ICT tool based on 7th Standard (grade) syllabus

a) Science and Social Science subjects as preliminary targets

b) Utilizing multimed ia tools

c) Integrate available resources and develop additional materials

d) Develop and establish internal dissemination system

2. Facilitating the selected rural schools to receive the system

a) Capacitating the teachers to implement the tool

b) Capacitate the students to operate the system

3. Extend the application level of ICT tool to make it as interactive

a) Select three schools located within adjoining villages

b) Facilitate these schools to have an interactive link

c) Create and run permanent system administrative unit in the Project site

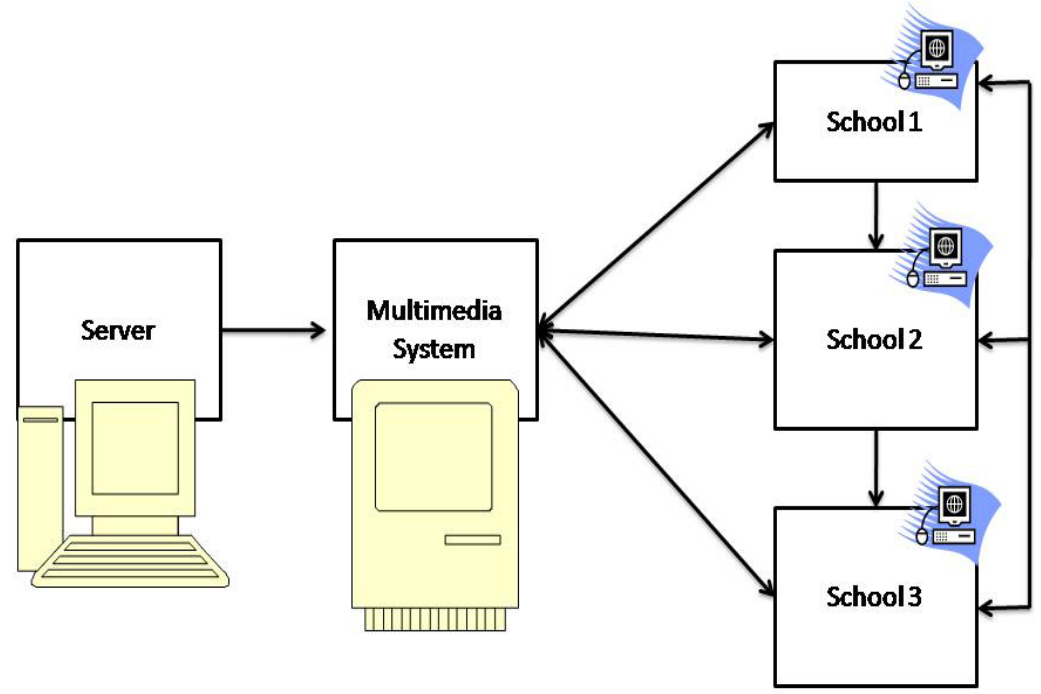

Figure 1. Connectivity of Server and Multimedia with various Schools 


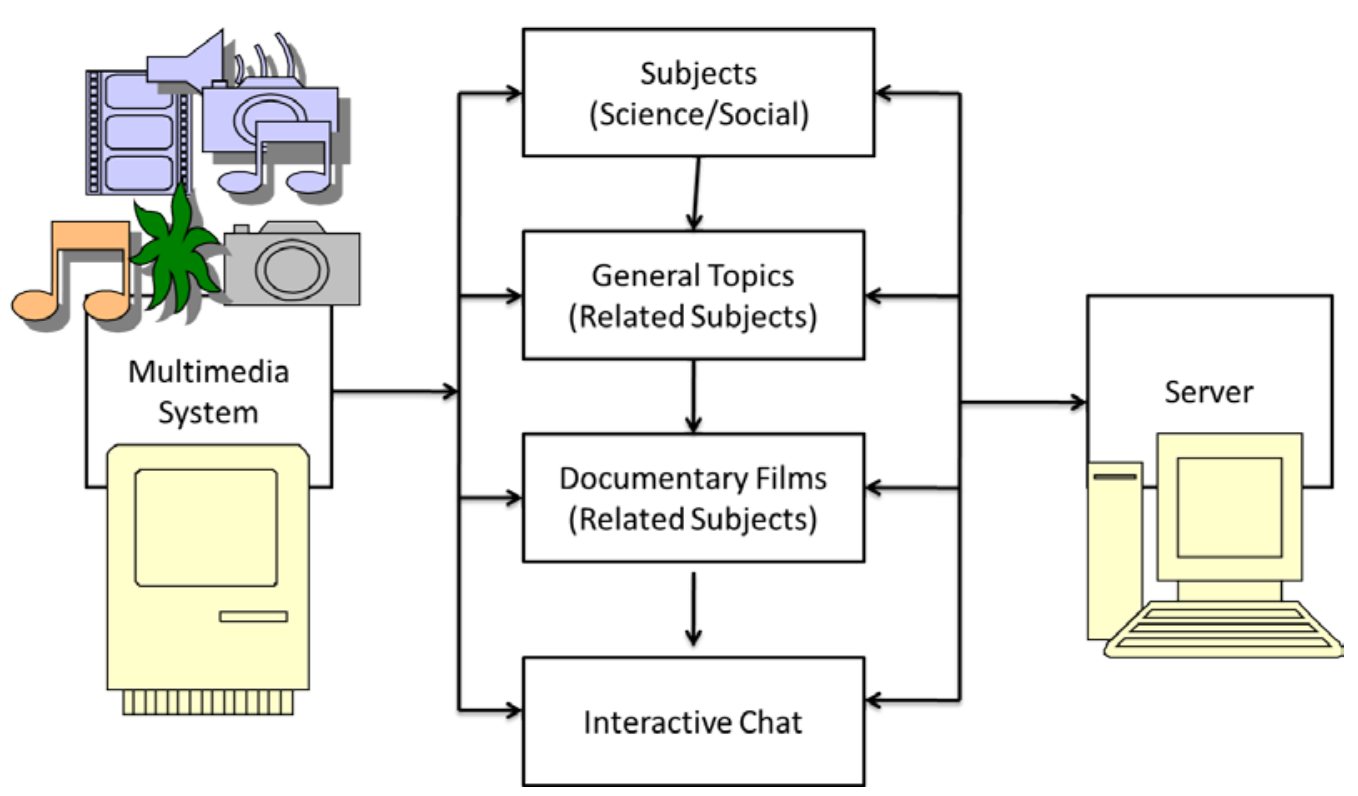

Figure 2. Aspects in Multimedia System

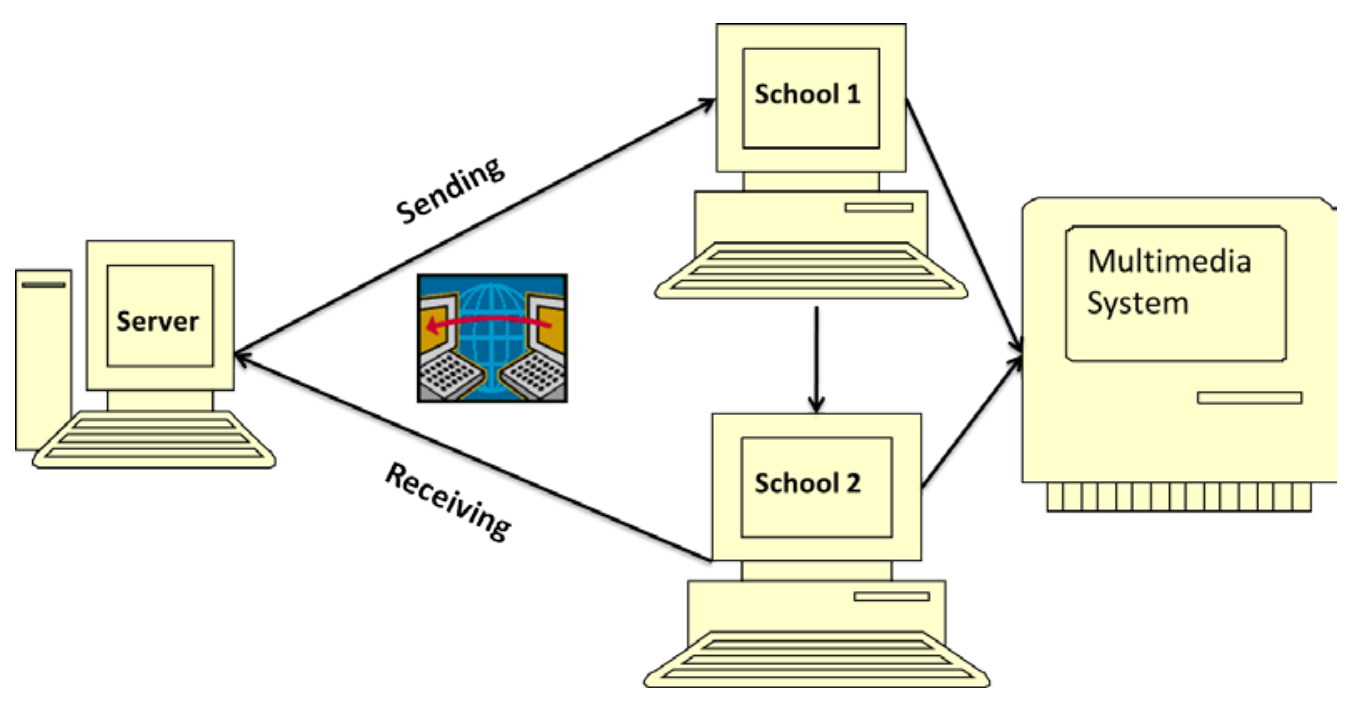

Figure 3. Connectivity of Server with Schools

The first step is the development of ICT based teaching learning tool for 7 th Standard. The project focused the 7th Standard students as a preliminary step. There are psychological and educational justifications to stress the relevance of selecting 7th Standard as the basic unit and are described below,

\section{A. Psychological}

i. Age: The age of 7th Standard student is a major factor for choosing this group as the beneficiaries. Normally a child will get into 7th Standard when he/she turns 12 years of age. This age is a turning point towards teenage or adolescence. At 12, the children are standing in between their innocent childhood and adolescence. Adolescence will lure them to fantasies. This is a critical age where proper care, guidance and counseling shall be imparted. The major relevance of selecting these age group children as beneficiaries is that they can be easily inducted with novel ideas and prompt them to develop their skills in proper channel.

ii. Vulnerability: This age group child is vulnerable to any external or internal coercion. The negative influences will hamper their lives and will end up in dropout or child labor. A positive change in education through opulent mechanisms can coax the students to pursue their studies in an interesting environment.

iii. Attitude: The attitudinal changes appear at this age among children should be channelized in a proper 
to cultivate virtues in their minds. Through creating sophisticated classrooms with interactive support systems to procure answers for their queries, the projects ultimately aim at molding tomorrow's youth with creative talents.

iv. Behavior: Major behavioral problems start at this age. The project evolved to promote the creative skill in Computer Science Students in our college to participate in societal welfare and development programmes. This will harness the negative impulses among school children to deviate from studies and will allure them to education. The College students will engineer their talents in a productive and innovative manner and it will give them responsibility in education and their role in nation building.

\section{B. Educational}

i. Drop out: This age group is prone to school dropout as per various studies by different agencies and Sarva Siksha Abhiyan. This project aims to curtail the alarming rate of dropouts in the State.

ii. Child labour: As an industrial location, State possesses numerous industries, small, medium and large. Poverty, illiteracy, socio-economic background etc play a major role in this condemned crime. This is a pioneer attempt by an academic institution to lend helping hands in a bigger way to erase child labour from our country.

iii. Lack of facilities: Rural Schools in Tamil Nadu face inadequate infrastructure and other facilities. It does not have proper and facilitated rooms, desks, tables, benches, boards or other materials to support effective learning and teaching environment.

iv. Inadequate Teachers: The Teacher student ratio is 1:65/1:75 in rural schools in Tamil Nadu. This affects the discipline, learning environment and communication channels.

v. Lack of teaching aids: Govern ment rural schools in Tamil Nadu rely on traditional chalk and talk methods and devoid of any modern teaching tools or aids to entice the students towards learning.

vi. Poor economic status: The poor economic status of the schools is a major drawback in making the education system interesting attractive to the students.

As mentioned earlier, the above methods can be implemented using a multimedia web application; these modules can be installed in 3 or 4 nearby rural schools initially to acquire a quality education. Standard (grade) VII can be taken into account, initially. Programming tools like Visual Studio and Oracle are used to design a website, then to develop a server for storing all the data. Also, these programming tools will help to integrate the website with the server. The Multimedia designing tools Adobe Flash, Adobe Photoshop, Windows Movie Maker, Adobe Dreamweaver, Maya 3D and Adobe Premier Pro helps to prepare the data (course materials) in the form of image, audio, video, animation etc. An interactive chat room can be developed to create an interaction between different regions of teachers and students. This enables to share knowledge between them.

School teachers prepare and teach academic, technical, vocational or specialized subjects at public and private secondary schools. The most important Essential Skills for Secondary School Teachers are: Critical Thinking, Reading Text, Document Use, Writing, Numeracy, Oral Communication, Thinking Skills, Problem Solving, Decision Making, Job Task Planning and Organizing, Significant Use of Memory, Finding Information, Working with Others, Computer Use, Continuous Learning, and Generate Notes. They participate in a variety of learning opportunities such as courses offered by school districts, ministries of education, universities' faculties of education, professional associations, and subject-area associations. They join professional networks, engage in research activities and read books and journals in order to improve their practices and enhance student learning. Continuous learning is strongly promoted by governments, school boards and teachers' associations, and some provinces may require continuous learning to maintain licensure.

School teachers must be positive, flexible, patient and enjoy working with people. They should be able to see the potential in all students and demonstrate enthusiasm and optimis $\mathrm{m}$. They need to show respect for all students and be able to accept differences. Computer use skills will become increasingly important as more courses are offered on-line and traditional classes incorporate more computer-assisted learning. Hence, this proposal helps to cater the needs of both students and teachers.

\section{CONCLUSION}

In the global world, India has to compete with many countries on various aspects besides many difficulties. Thus, the rural India can overcome the existing problems in schools by installing this project. Hence, this change in the teaching, learning strategy will provide quality education at affordable cost for rural based schools, changes and improves the teaching, learning strategy, improve the slow learners, equip and updates the knowledge of teachers.

As a solution to overcome the existing problems in schools, this paper proposes an Interactive Teaching Learning Tool. The objectives of this paper are to evolve an ICT tool for teaching - learning, develop an internal mechanis $m$ to run the tool, facilitate the schools to receive and operate the tool, and capacitate teachers, students to utilize the tool.

\section{ACKNOW LEDGMENT}

This research proposal is submitted to National Council of Education Research and Training (NCERT), New Delhi, India for financial assistance. We are waiting for the approval. 


\section{REFERENCES}

[1] Jenna Wroblewski, What Education Means to, Mehttp://nfl.packers.com/fan_zone/contests/badger_ mutual_essay_contest/essay080120.pdf.

[2] History of education in the Indian subcontinent, http://en.wikipedia.org/wiki/History_of_education_i n_the_Indian_subcontinent.

[3] Right to Education (RTE), http://mhrd.gov.in/rte.

[4] Sarva Shiksha Abhiyan, en.wikipedia.org/wiki/SSA.

[5] Michael Ward, Prem Kalra and Anupam Rastogi, India Infrastructure Report - Rural Infrastructure, Published in India by Oxford University Press, New Delhi, pp. 286-313, 2007.

[6] Sarva Shiksha Abhiyan, www.ssa.tn.nic.in/.

[7] Research Abstracts on Education, 1998 - 2009, Documentation Centre for Women and Children, National Institute of Public Cooperation and Child Development, New Delhi, 2010.

[8] Nirupam Bajpai, Ravindra H. Dholakia and Jeffrey D. Sachs, Scaling up Primary Education Services in Rural Tamil Nadu: Public Investment Requirements and Reform. pp. 1-52, 2008.

[9] Azim Premji Foundation, The Social Context Of Elementary Education in Rural India, published by Azim Premji Foundation, Bangalore, pp. 1-51, 2004.

[10] Dr. Arun C. Mehta, Infrastructure in Elementary Schools: A Preliminary Analysis of DISE, published by District Information System for Education and National University of Educational Planning and Administration, 2008-09 Data.

\section{BIBLIOGRAPHY}

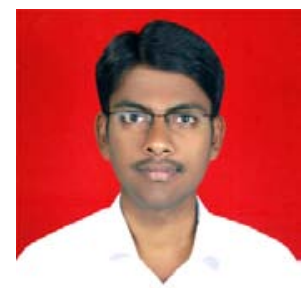

H. Vignesh Ramamoorthy received his M.Sc (Software Engineering) from Anna University, Chennai in 2010, MCA from Bharathiar University in 2012, Post Graduate Diploma in Mobile Computing from Annamalai University in 2012. He is currently working as an Assistant Professor in Sree Saraswathi Thyagaraja College, Pollachi, Coimbatore District and also pursuing his part time M.Phil in the same institution. He has presented 10 papers in National Conferences, 7 in International Conferences and has 11 publications in various refereed international journals. His areas of interests are Multimedia, Mobile Computing and Web Development.

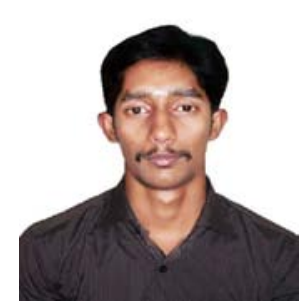

P.J. Balakumaran received his M.Phil in Computer Science from Sree Saraswathi Thyagaraja College, Pollachi in 2012, M.Sc Computer Science in Sree Ramu College of Arts and Science, Pollachi in 2011. He is currently pursuing his Ph.D in Computer Science in Sree Saraswathi Thyagaraja College, Pollachi, Coimbatore District. He has presented papers in National Conferences. His areas of interest are Data Mining, E Governance and Multimedia.

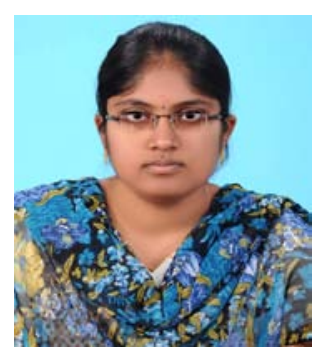

H.Karthikeyani received her Bachelor of Science in Mathematics from Nallamuthu Gounder Mahalingam College (affiliated to Bharathiar University, Coimbatore) in 2012, Bachelor of Education in Mathematics from Tamilnadu Teachers Education University, Chennai in 2013. Currently she is pursuing her Master of Science in Mathematics at Nallamuthu Gounder Mahalingam College, Pollachi. She has presented many research papers in Symposiums. Her broad fields of research are Operations Research, Multimedia and Child Psychology. 